\title{
First-line chemotherapy of advanced or metastatic breast cancer (MBC) with docetaxel and doxorubicin in Indonesia: results from A phase II trial
}

\author{
Abdulmuthalib ${ }^{*}$, Idral Darwis ${ }^{f}$, Nugroho Prayogo ${ }^{*}$, Sutjipto $^{\#}$
}

\begin{abstract}
Abstrak
Doxorubicin dan docetaxel masing-masing dikenal sebagai obat sitotoksik yang aktif untuk pengobatan kanker payudara metastatik (KPM). Kombinasi keduanya juga telah memperlihatkan derajat aktivitas yang tinggi sebagai kemoterapi lini kedua untuk KPM. Penelitian ini bertujuan untuk mengevaluasi keampuhan dan keamanan kombinasi docetaxel-doxorubisin sebagai kemoterapi lini pertama untuk penderita KPM di Indonesia. Sebanyak 26 pasien wanita berusia 31-65 tahun dengan KPM diikutsertakan dalam studi. Pasien belum pernah mendapat taxane atau doxorubicin kumulatif sebesar $250 \mathrm{mg} / \mathrm{m} 2 \mathrm{serta}$ tidak menderita penyakit jantung. Terapi terdiri dari doxoubicin $50 \mathrm{mg} / \mathrm{m}^{2}$ sebagai bolus intravena (IV) diikuti satu jam kemudian oleh docetaxel $60 \mathrm{mg} / \mathrm{m}^{2}$ dengan infus IV selama 1 jam, setiap 3 minggu untuk 6 siklus. Premedikasi dengan kortikosteroid oral diberikan sehari sebelum kemoterapi sampai hari kedua setiap siklus. Fraksi ejeksi ventrikel kiri direkam di awal studi dan setelah siklus ke-6. Di akhir studi, secara total telah diberikan 156 siklus kemoterapi. Lima dan 11 orang pasien mengalami respons komplit (RK) dan parsial (RP), berturut-turut, yang menjadikan respons keseluruhan terbaik sebesar 61,54\%. Tiga orang pasien dengan metastatis hepar luas tampak hilang sama sekali setelah 6 siklus. Toksisitas derajat 3-4 tersering adalah leukopenia (80,77\%) dan febrile neutropenia (5,77\%). Leukopenia biasanya singkat, dan terutama terjadi pada siklus pertama dan kedua serta tidak membutuhkan penurunan dosis. Tidak ada pasien yang mengalami gagal jantung. Terdapat satu kematian akibat penyakit yang progresif setelah 6 siklus. Kombinasi doxorubicin 50 mg $/ \mathrm{m}^{2}$ dan docetaxel $60 \mathrm{mg} / \mathrm{m}^{2}$ tampak aktif sebagai kemoterapi lini pertama pada KPM, khususnya pada pasien dengan metastatis hepar, dengan profil toksisitas yang dapat ditatalaksana. (Med J Indones 2005; 14: 20-5)
\end{abstract}

\begin{abstract}
Doxorubicin and docetaxel as a single agent are known as active cytotoxic agents for the treatment of metastatic breast cancer $(M B C)$. Their combination has also shown to be highly active as a second-line chemotherapy of MBC. This study was design to evaluate the efficacy and safety of docetaxel-doxorubicin combination as first line chemotherapy of MBC patients in Indonesia. Twenty-six female patients between 31-65 years old with advanced or MBC was enrolled. No prior taxane or cumulative doxorubicin of $250 \mathrm{mg} / \mathrm{m}^{2}$ was allowed and patients should not have a heart disease. Treatment consisted of doxorubicin $50 \mathrm{mg} / \mathrm{m}^{2}$ as intravenous (IV) bolus followed one hour later by docetaxel $60 \mathrm{mg} / \mathrm{m}^{2}$ by IV infusion over 1 hour every 3 weeks for 6 cycles. Premedication with oral corticosteroid was administered a day prior to chemotherapy until the second day of each cycle. Left ventricular ejection fraction was recorded at baseline and after the $6^{\text {th }}$ cycle. At the end of study, a total of 156 cycles of chemotherapy have been delivered. Five and 11 patients had a complete response $(C R)$ and partial response (PR), respectively, which accounted for a $61.54 \%$ best overall response. Three patients with extensive liver metastases showed complete disappearance after 6 cycles. Most frequent grade 3-4 toxicities were leukopenia (80.77\%) and febrile neutropenia (5.77\%). Leukopenia was usually short in duration, occurred mainly during the first and second cycle and did not require dose reduction. No patient developed heart failure. There was one death due to progressive disease after 6 cycles. Combination of doxorubicin $50 \mathrm{mg} / \mathrm{m}^{2}$ and docetaxel $60 \mathrm{mg} / \mathrm{m}^{2}$ was sufficiently active as first-line chemotherapy of $M B C$, especially in patients with liver metastases, with a manageable toxicity profile. (Med J Indones 2005; 14: 20-5)
\end{abstract}

Keywords: docetaxel, doxorubicin, advanced or metastatic breast cancer, phase II trial, anthracycline and taxane combination

\footnotetext{
*Division of Hematology-Medical Oncology, Department of Internal Medicine, Faculty of Medicine University of Indonesia, Jakarta, Indonesia

${ }^{f}$ Division of Head, Neck, and Breast, Department. of Surgery, University of Indonesia Faculty of Medicine/Dharmais National Cancer Center, Jakarta, Indonesia,

\# Department of Surgery, Dharmais National Cancer Center, Jakarta, Indonesia
}

Breast cancer is the second most common malignant disease in Indonesia. There are 150 new cases per year in Dharmais National Cancer Center, ${ }^{1}$ while in Asia-Pacific Region new cases are estimated to be 200,000 patients per year or $13 \%$ of all cancers. ${ }^{2}$ Locally advanced and metastatic breast cancers are frequently found in Indonesian patients, which would need an active regimen of chemotherapy. 
Docetaxel (Taxotere ${ }^{\circledR}$ ), a taxane, has been known as one of the most active cytotoxic agents in the management of breast cancer, either as a second-line or first-line treatment. Taxanes induce cytotoxicity by binding to tubulin, promoting microtubule assembly, and inhibiting microtubule depolymerization, thereby disrupting the equilibrium within the microtubule system and ultimately leading to cell death. ${ }^{3}$ In the pretaxane era, doxorubicin-containing regimen has resulted an improve response rate and survival of metastatic breast cancer patients. Anthracycline like doxorubicin exert their cytotoxicity by inducing DNA damage through an inhibition of topoisomerase II.

In the management of advanced or metastatic breast cancer (MBC), a more active regimen is required. Combination of two or more cytotoxic agents has been practiced since 1970s to increase treatment efficacy. They generally show a greater efficacy than each of the single agent. ${ }^{4}$ Based on their mechanism of action and different toxicity profiles, there is a clear reason to combine docetaxel and doxorubicin in the treatment of MBC. One concern is the cardiotoxicity, which has been shown previously with the combination of paclitaxel and doxorubicin. The major side effect of docetaxel is neutropenia; it also dosedependent but not schedule-dependent and noncumulative. ${ }^{5}$

This phase II trial was aimed to confirm the efficacy of docetaxel and doxorubicin as first line chemotherapy of advanced and MBC. The second objective was to gather safety data on patients receiving this combination.

\section{METHODS}

\section{Eligible Patients}

Female patients between 18-70 years were eligible for this study after they signed a written consent. Other inclusion criteria were histopathologically or cytologically proven breast cancer, locally advanced or metastatic disease, WHO performance status below grade 2, and measurable disease. Bidimensionally measurable lesion should meet at least $2 \times 1 \mathrm{~cm}$ by CT-scanning or ultrasonography, more than $1 \times 1 \mathrm{~cm}$ lesion by Xray (in lungs), or $1 \times 1 \mathrm{~m}$ lesion by physical examination (i.e. skin nodules and superficial lymph nodes). Patients should not have prior chemotherapy for metastatic disease. Prior neoadjuvant and/or adjuvant chemotherapy was allowed if at least there was a 12-month interval between the end of chemotherapy and the first relapse. Prior cumulative dose of doxorubicin should not exceed $250 \mathrm{mg} / \mathrm{m} 2$ and epirubicin should not exceed $450 \mathrm{mg} / \mathrm{m}^{2}$. Hormonal therapy, either for adjuvant and/ or metastatic disease (no more than 2 lines for metastatic disease) was allowed within a 4-week interval between the last treatment and study entry. Patients might have received radiotherapy, if it was not include the only site used to assess treatment response in the current study. It should have been at least 4 weeks since the last radiation. Adequate hematological, cardiac, renal, and hepatic functions were also required. Absolute neutrophil count (ANC) $>1.5 \times 10^{9} / 1$, platelets count $>100 \times 10^{9} / 1$; total serum bilirubin less than $1 \mathrm{X}$ upper limit of normal (ULN), AST and/ or $\mathrm{ALT} \leq 2.5 \mathrm{X}$ ULN,$\leq 3 \mathrm{X} \mathrm{ULN}$ if hepatic metastases were present; alkaline phosphatase $\leq 6 \mathrm{X}$ ULN (unless bone metastases were present in the absence of any severe disorder); creatinine $\leq 1.5 \mathrm{X}$ ULN. Normal cardiac function should be confirmed by leftventricular ejection fraction to be more than $50 \%$.

Patients were excluded if they were pregnant or lactating. Patients with child bearing potential should be on adequate contraception. Other exclusion criteria were current or past malignancy (other than nonmelanoma skin cancer or excised in situ cervical cancer). Patients with history or the presence of brain or leptomeningeal involvement; patients with AST/ ALT more than 1.5 X ULN associated with alkaline phosphatase more than $2.5 \mathrm{X}$ ULN; patients with $20 \%$ or more of the bone marrow irradiated were excluded. Further non-eligible patients included those who had left chest radiotherapy, active infection or other serious underlying medical condition not compatible with study entry, symptomatic peripheral neuropathy more than grade 2 by NCI-CTC scale, history of significant neurological or psychiatric disorders including provision dementia that would prohibit the understanding and giving of informed consent. Patients with congestive heart failure or angina pectoris even if it was medically controlled, uncontrolled hypertension or arrhythmia, prior history of myocardial infarction, peptic ulcer disease, unstable diabetes mellitus or other contraindication for the use of corticosteroids, concurrent treatment with other experimental agents, other anti-cancer therapy, concomitant treatment with 
corticosteroids except for premedication were also excluded.

\section{Regimen and duration of treatment}

This was an open-label, non-randomized phase II trial. Each patient was scheduled to receive doxorubicin 50 $\mathrm{mg} / \mathrm{m}^{2}$ (15 minutes, i.v. bolus) followed one hour later by docetaxel (Taxotere ${ }^{\circledR}$, Aventis Pharma, France) 60 $\mathrm{mg} / \mathrm{m}^{2}$ on day 1 every 3 weeks. Dose reduction, treatment delay and treatment discontinuation were planned in accordance to the hematological and/or non-hematological toxicities.

A routine prophylactic corticosteroid medication was required before and during the first three days of each treatment cycle. Dexamethasone or equivalent $8 \mathrm{mg}$ per os bid to be given at days $-1,1,2$ (day 1 is the day of docetaxel administration). The use of prophylactic broad- spectrum antibiotics was not allowed in the first cycle, but would have considered in the next cycles in accordance with local clinical practice.

All patients received 6 cycles of treatment unless there was unacceptable toxicity or progression of disease. Patients who responded were allowed to receive an additional three cycles of docetaxel only $\left(75 \mathrm{mg} / \mathrm{m}^{2}\right)$. Treatment would be stopped if patient had unacceptable toxicities, disease progression, or no response after 6 cycles in a stable disease.

\section{Assessment}

Patients were assessed if they complete more than 2 cycles with at least one follow-up visit. Patients who showed early progression were separated. Duration of response and time to progression in patients with partial response (PR) were calculated from the day of first cycle to the time of progression or the beginning of additional antitumor therapy. Duration of response in patients with complete response (CR) was calculated from the date when $\mathrm{CR}$ was noted. Time to progression for CR patients was calculated from the start of therapy. Patient's response was recorded according to WHO criteria.

\section{Safety}

Assessment of the safety included neurotoxicity, WHO performance status, vital signs, laboratory measurements (hematological, renal, and liver function tests), and toxicity assessment according to NCI-CTC grading.

\section{Follow-up}

Patients were observed for one month after the last infusion to the end of the study to document any late side effects. Then, patients were followed every 3 month until they died to document follow-up until resolution of all side effects, progression if the patients was removed from the study before progression, further therapy, starting date and the response to further therapy, if any.

\section{Other medication}

G-CSF was not routinely administered and was given only if the patient had prior episode of febrile neutropenia in early cycle. No primary prophylactic administration (from the first cycle) was permitted. Antiemetic prophylactic was recommended. All medications given prior to, during, and after every cycle were recorded and the reason for its administration was reported.

\section{RESULTS}

Twenty-six female patients, aged 31 to 65 years old, were enrolled during the study period, i.e. from March 1998 to January 2000. Six among them were unmarried women. Twenty-five patients were histopathologically confirmed breast cancer, while the other one had cytological confirmation. Clinical staging showed 13 patients with stage IIIB disease, 10 patients in stage $\mathrm{IV}$, and 3 patients had had recurrent metastases. Liver metastases were found in 3 patients. WHO performance status (PS) showed 11 patients with PS-1 and 15 patients with PS-0. At the end of the trial, 22 patients had improved or remained stable at PS-0. Two patients stayed at PS-1. One patient moved from PS-1 to PS-2 and another patient moved from PS-1 to PS-4.

Table 1. Patients' characteristics

\begin{tabular}{ll}
\hline Number of patient & 26 patients \\
\hline Median age & $46(31-65)$ years \\
\hline WHO-Performance & $0: 15(57.6 \%)$ patients \\
Status (PS) & $1: 11(42.3 \%)$ patients \\
\hline Number of organ & 1 organ $: 3.85 \%$ \\
involved & 2 organs $: 69.23 \%$ \\
& 3 organs $: 19.23 \%$ \\
& 4 organs $: 7.69 \%$ \\
\hline Clinical staging & Stage IIIB $: 13(50 \%)$ cases \\
& Stage IV $: 10(38.46 \%)$ cases \\
& Recurrent $: 3(11.54 \%)$ cases \\
\hline
\end{tabular}


Partial remission was achieved by 22 (84.61\%) patients after three cycles, and at the end of the sixth cycle, the response rate was $61.54 \%$ with $5(19.23 \%)$ patients achieved complete remission. Only $10(38.46 \%)$ patients showed progressive disease. Three patients with extensive liver metastases at baseline showed no lesion after six cycles.

Table 2. Patient's response to treatment

\begin{tabular}{lcc}
\hline After 3 cycles & $\mathbf{n}$ & $\mathbf{\%}$ \\
Partial response (PR) & 22 & 84.62 \\
No change & 3 & 11.54 \\
Progression of disease & 1 & 3.84 \\
Best overall response (PR) & & 84.61 \\
\hline After 6 cycles & & \\
Complete Response (CR) & 5 & 19.23 \\
Partial Response & 11 & 42.31 \\
Progressive Disease & 10 & 38.46 \\
Best Overall Response (CR+ PR) & & 61.53 \\
\hline
\end{tabular}

Major side effect was myelosuppression (Table 3). It was relatively short in time and no one required treatment delay due to leukopenia. On day-7 after the administration of docetaxel-doxorubicin combination, $67.95 \%$ and $5.77 \%$ patients had grade 3/4 leukopenia and febrile neutropenia, respectively. However, on day-14, only $12.82 \%$ patients who were in grade 3 and 4 of leukopenia. No patient was leukopenic on day-20 or day-21 (the day before the administration of the next cyle).

Table 3. Hematological toxicity profile

\begin{tabular}{lccc}
\hline & \multicolumn{3}{c}{$\begin{array}{c}\text { \% of cycles with grade 3/4 } \\
\text { (NCl term) }\end{array}$} \\
\cline { 2 - 4 } & Day 7 & Day 14 & Day 21 \\
\hline Leukopenia & 67.95 & 12.82 & 0 \\
Leukopenia with infection & 1.28 & 0 & 0 \\
Febrile neutropenia & 5.77 & 0 & 0 \\
Anemia & 2.56 & 2.56 & 0.64 \\
Thrombocytopenia & 0 & 0 & 0 \\
\hline
\end{tabular}

Other side effects, which were relevant to the treatment, are given in Table 4. Alopecia was the most frequent side effect. Nausea and vomiting were reported in $41.66 \%$ courses and usually mild (grade 1 or 2). Mucositis or stomatitis was observed in 35.9\% of courses. Asthenia was found in $37,17 \%$ of courses but only $3.85 \%$ had grade 3 ; the others remained in the grade 1 or 2 .
Table 4. Non-hematological side effects

\begin{tabular}{lcc}
\hline & \multicolumn{2}{c}{ \% of cycles } \\
\cline { 2 - 3 } & Grade $1 / 2$ & Grade $3 / 4$ \\
\hline Nausea/ vomiting & 38.46 & 3.2 \\
Alopecia & 100 & 0 \\
Asthenia & 33.32 & 3.85 \\
Stomatitis/mucositis & 34.62 & 1.28 \\
Diarrhea & 26.93 & 1.92 \\
Pain & 16.67 & 1.92 \\
Paresthesia & 22.43 & 0 \\
Peripheral edema & 8.97 & 0 \\
Loss of taste & 1.28 & 0 \\
Headache & 10.26 & 0.64 \\
Nail disorders & 73.08 & 0 \\
\hline
\end{tabular}

Loss of taste and paresthesia were also noted which indicated a mild neurotoxicity. Peripheral edema occurred in a low number and also mild (Table 4). No patients required treatment discontinuation or delayed schedule. Echocardiography assessment showed that all patient, except two, had left-ventricular ejection fraction (LVEF) of more than $60 \%$. Only 5 patients had $20-30 \%$ decrease of LVEF at the end of the study (Table 5).

Table 5. Echocardiography assessment showed by the change in $\mathrm{LVEF}$

\begin{tabular}{|c|c|c|c|}
\hline $\begin{array}{c}\text { Patients } \\
\text { No. }\end{array}$ & $\begin{array}{c}\text { Baseline } \\
(\%)\end{array}$ & $\begin{array}{c}\text { End of study } \\
(\%)\end{array}$ & $\begin{array}{c}\text { Change } \\
(\%)\end{array}$ \\
\hline 1. & 74 & 44 & +4.05 \\
\hline 2. & 71 & 75 & +5.63 \\
\hline 3. & 76 & 70 & - 7.89 \\
\hline 4. & 68 & 53 & -22.06 \\
\hline 5. & 82 & 61 & -25.61 \\
\hline 6. & 80 & 68 & -15 \\
\hline 7. & 66 & 73 & +10.61 \\
\hline 8. & 74 & 75 & +1.35 \\
\hline 9. & 80 & 66 & -17.5 \\
\hline 10. & 69 & 66 & -4.35 \\
\hline 11. & 78 & $\mathrm{NE}$ & $\mathrm{NE}$ \\
\hline 12. & 82 & 67 & -18.29 \\
\hline 13. & 79 & 65 & -17.72 \\
\hline 14. & 65 & 68 & +4.61 \\
\hline 15. & 78 & 82 & +5.13 \\
\hline 16. & 82 & 65 & -20.73 \\
\hline 17. & 59 & 67 & +8 \\
\hline 18. & 78 & 63 & -19.23 \\
\hline 19. & 59 & 61 & +3.39 \\
\hline 20. & 80 & 63 & -21.25 \\
\hline 21. & 78 & 83 & +6.41 \\
\hline 22. & 62 & 76 & +22.58 \\
\hline 23. & 76 & 73 & -3.95 \\
\hline 24. & 80 & 84 & +5 \\
\hline 25. & 84 & 71 & -15.48 \\
\hline 26. & 78 & 60 & -23.08 \\
\hline
\end{tabular}




\section{DISCUSSION}

Ideally, a combination therapy should meet three criteria, i.e: each component should have single-agent activity with no cross-resistance; there should be preclinical evidence of synergy between the components; and the components should have non-overlapping safety profile. ${ }^{6}$ However, this ideal condition is rarely met and treatment combinations were continually tried out. One of the most frequently used combinations in the treatment of advanced breast cancer is the combination of an anthracycline and a taxane. In this study, we used the combination of doxorubicin and docetaxel. When use as a single agent, doxorubicin has a response rate between 40$50 \%$ in the treatment of MBC patients. ${ }^{7}$ Docetaxel, a new antimicrotubule agent synthesized in 1986, has demonstrated a high acitivity in the treatment of advanced breast cancer. A prospective randomized trial comparing the efficacy of docetaxel and doxorubicin in MBC showed that the objective response by docetaxel was significantly higher doxorubicin $(47.8 \%$ v $33.3 \%$; $\mathrm{p}=0.008){ }^{8}$

Our current study has shown an overall response rate of $61.5 \%$, including $5(19.2 \%)$ patients with complete response. This result was comparable to other studies. A study by Sparano et al, showed an objective response rate of 57\% (95\% CI: 42-70\%) among 51 eligible patients treated with doxorubicn $60 \mathrm{mg} / \mathrm{m}^{2}$ and docetaxel $60 \mathrm{mg} / \mathrm{m}^{2}$ plus G-CSF. Complete response was achieved in three patients. ${ }^{9}$ A recent report from Japan showed a slightly higher objective response rate of $70 \%$ (95\% CI: $53-84 \%$ ) among 37 women with metastatic breast cancer assessable for efficacy. ${ }^{10}$

Although the way of combining two active agents concurrently is recently criticized, (Miles) some experts has started a phase III trial. Nabholtz et al conducted the first study comparing docetaxeldoxorubicin (AT) with a standard regimen of doxorubicin-cyclophosphamide (AC) as first line chemotherapy for metastatic breast cancer. They found that AT combination gives significantly greater overall response rate compared to $\mathrm{AC}$ combination ( $59 \%$ vs. $47 \%, \mathrm{p}=0.0009$ ). The regimen dose used was doxorubicin $50 \mathrm{mg} / \mathrm{m}^{2}$ and docetaxel $75 \mathrm{mg} / \mathrm{m}^{2}$ ( $\mathrm{n}=214$ patients). ${ }^{11}$ Their result was similar to our study despite the higher dose of docetaxel they used. Another schedule to deliver cytotoxic agents is sequential administration of these drugs. Although interesting, initial report showed a quite similar overall response rate of $71 \%$ after delivering 4 cycles of docetaxel at $100 \mathrm{mg} / \mathrm{m}^{2}$ every three weeks followed by 4 cycles of doxorubicin and cyclophosphamide (AC $60 / 600 \mathrm{mg} / \mathrm{m}^{2}$ ) every three weeks. ${ }^{12}$

Combination therapy may be particularly useful in patients needing a prompt reduction in tumor burden (e.g. patients with visceral disease and fast-growing tumors).(Miles) Our study showed three patients with extensive liver metastasis develop complete disappearance of hepatic lesions after 6 cycles. Although it have not studied in detail, this benefit could be true. The first phase III trial by Nabholtz showed that a higher response rate was produced by AT combination in all poor-prognosis subgroups, that include visceral involvement and $\geq$ organs 3 involved, compared to $\mathrm{AC}$ group (odds ratio $\mathrm{AT} / \mathrm{AC}=1.7 ; 95 \% \mathrm{CI} 1.2$ to 2.5; $\mathrm{p}=0.007)$. An interim report by Friedrichs et al also concluded that patients with high-risk visceral metastases appear to derive benefit from the combination therapies with taxanes. ${ }^{13}$

Neutropenia was expected to occur since myelosuppresion is the most common side effect of chemotherapy. Nabholtz's study found that the incidence of grade 3/4 neutropenia was higher with AT than with AC $(97 \% v 88 \% ; \mathrm{p}=0.01)$. Febrile neutropenia and occurred in $33 \%$ of AT group compared to $10 \%$ of $\mathrm{AC}$ group patients $(\mathrm{p}<0.001)$, whereas infection grade $3 / 4$ occurred in $8 \%$ of AT group $v 5 \%$ of AC group patients $(\mathrm{p}=0.01)$. Our patients showed less hematological side effects (Table 3) compare to their study, but it could be due to the lower dose of docetaxel we used. Aihara et al found 88\% grade 3/4 neutropenia and $40 \%$ febrile neutropenia using regimen dosages that similar to our study. Alteration of regimens from 3 -weekly to weekly administration of docetaxel has been evaluated to produce less hematological toxicities, either as monotherapy or combined with anthracyclines. (Friedrichs)

Fluid retention is associated with docetaxel and predictable to all phase II studies using corticosteroid premedication. On the other hand, doxorubicin was associated with a risk of developing congestive heart disease (CHF). Cardiac toxicity was also the most frequent reason for discontinuation of doxorubicin treatment, therefore LVEF monitoring is required. Docetaxel does not alter the pharmacokinetics of doxorubicin which was seen with paclitaxel. Fluid retention by docetaxel was less likely to lead to treatment discontinuation. Fluid retention syndrome $\leq$ grade 2 was observed in $25 \%$ of patients in Aihara's study, but none of their patients developed CHF or 
asymptomatic decrease of LVEF to less than $50 \%$. In the phase III trial by Nabholtz, the incidence of CHF was not significant in patients receiving $\mathrm{AT}$ or AC regimen, but LVEF decrease of 20 points or more occurred more frequently with AC compared with AT $(13 \% \vee 6 \% ; \mathrm{p}=0.03)$.

In setting a new standard in the treatment of metastatic breast cancer, Nabholtz has drawn several points favorable to the combination of doxorubicin and docetaxel. This combination appears capable of improving survival and is superior to doxorubicin plus cyclophosphamide, particularly in poor-prognosis patient. ${ }^{14}$

\section{CONCLUSION}

In conclusion, this phase II trial demonstrated that the combination of docetaxel $60 \mathrm{mg} / \mathrm{m}^{2}$ and doxorubicin $50 \mathrm{mg} / \mathrm{m}^{2}$ was active in the first-line chemotherapy of advanced or metastatic breast cancer patients. Side effects occurred, as toxicities were expected with the use of cytotoxic agents. These side effects were acceptable by patients and could be manage accordingly. At present, docetaxel and doxorubicin combination seems to be a promising approach in improving the course of metastatic breast cancer disease. Altering schedule could be recommended for patients who are not tolerant to side effects.

\section{REFERENCES}

1. Medical Record Department of Dharmais National Cancer Center. Medical records of inpatient and outpatient breast cancer patients. Jakarta; 1998. Unpublished data.

2. Mittra I, Badwe RA. Breast cancer: flow chart for diagnosis and staging of cancer in developed and developing countries. Geneva: UICC;1998, p. 147-68.

3. Aapro MS. Combination of docetaxel/ vinorelbine for metastatic breast cancer. Oncology 1997;11(8 Suppl. No.8):46-9.
4. Piccart MJ, Di Leo A. Future prospect of docetaxel (Taxotere) in front-line therapy. Semin Oncol 1997;24(4 Suppl. 10) S10-27-S10-33.

5. Pronk LC, et al. Docetaxel and ifosfamide in patients with advanced solid tumors: results of a phase 1 study. Semin Oncol 1998;25(Suppl 2):23-8.

6. Miles D, Von Minckwitz G, Seidman AD. Combination versus sequential single-agent therapy in metastatic breast cancer.Oncologist 2002;7(suppl 6):13-9.

7. Honig SF. Treatment of metastatic disease: Hormonal therapy and chemotherapy of the breast. Philadelphia: Lippincott Raven;1996: 669-734.

8. Chan S, Friedrichs K, Noel D, Pinter T, Van Belle S, Vorobiof $\mathrm{D}$, et al. Prospective randomized trial of docetaxel versus doxorubicin in patients with metastatic breast cancer. J Clin Oncol 1999; 17:2341-54.

9. Sparano JA, O’Neill A, Schaefer PL, Falkson CI, Wood WC. Phase II trial of doxorubicin and docetaxel plus granulocyte colony-stimulating factor in metastatic breast cancer: Eastern Cooperative Oncology Group Study E1196. J Clin Oncol 2000;18(12):2369-77.

10. Aihara T, Takatsuka Y, Itoh K, Sasaki Y, Katsumata N, Watanabe T, et al. Phase II study of concurrent administration of doxorubicin and docetaxel as first-line chemotherapy for metastatic breast cancer. Oncology 2003;64:124-30.

11. Nabholtz J-M, Falkson C, Campos D, Szanto J, Martin M, Chan S, et al. Docetaxel and doxorubicin compared with doxorubicin and cyclophosphamide as first-line chemotherapy for metastatic breast cancer: results of a randomized, multicenter, phase III trial. J Clin Oncol 2003;21(6):968-75.

12. Khayat D, Chollet $\mathrm{P}$, Antoine EC, Monfardini S, Ambrosini G, Benhammouda A, et al. Phase II study of sequential administration of docetaxel followed by doxorubicin and cyclophosphamide as first-line chemotherapy in metastatic breast cancer. J Clin Oncol 2001;19:3367-75.

13. Friedrichs K, Holzel F, Janicke F. Combination of taxanes and anthracyclines in first-line chemotherapy of metastatic breast cancer: an interim report. Eur J Cancer 2002; 38:1730-8.

14. Nabholtz J-M, Riva A. Taxane/anthracycline combinations: setting a new standard in breast cancer? Oncologist 2001;6(Suppl 3):5-12. 